\title{
Development and Validation of New Analytical Methods for the Determination of Ketorolac Tromethamine (A Non-Steroidal Anti-Inflammatory Agent)
}

\section{Duggirala Sree Harsha, Gunuputi Sushma and Mukthinuthalapati Mathrusri Annapurna*}

GITAM Institute of Pharmacy, GITAM (Deemed to be) University, Visakhapatnam, India

*Corresponding Author: Mukthinuthalapati Mathrusri Annapurna, GITAM

Institute of Pharmacy, GITAM (Deemed to be) University, Visakhapatnam, India.
Received: April 13, 2020

Published: May 04, 2020

(C) All rights are reserved by Mukthinuthalapati Mathrusri Annapurna., et al.

\begin{abstract}
Five new spectrophotometric methods have been established for the determination of Ketorolac tromethamine in pharmaceutical formulations. Ketorolac tromethamine is Non-steroidal anti-inflammatory drug used to treat pain. Ketorolac tromethamine is chemically known as k benzoyl-2,3-dihydro-1H-pyrrolizine-1-carboxylic acid. Ketorolac has shown absorption maxima at $323 \mathrm{~nm}$ in all the methods. Reagents used such as phosphate buffers (pH 5.0 and 8.0), acetate buffer (pH 4.7), 0.1N NaOH and borate buffer (pH 9.0). Ketorolac tromethamine obeys Beer-Lambert's law over the concentration range 5 - $30 \mu \mathrm{g} / \mathrm{ml}$ for all the above mentioned methods and all the methods were validated as per ICH guidelines.

Keywords: Ketorolac Tromethamine; Spectroscopy; Phosphate Buffer; Borate Buffer; Acetate Buffer; Sodium Hydroxide, Validation
\end{abstract}

\section{Introduction}

Ketorolac tromethamine is a nonsteroidal anti-inflammatory drug which exhibits pronounced analgesic and moderate antiinflammatory activity [1]. It is a synthetic pyrrolizine carboxylic acid derivative. Ketorolac tromethamine (Figure 1) is used to treat moderately severe pain and inflammation, usually after surgery [2]. Ketorolac tromethamine works by blocking the production of prostaglandins, compounds that cause pain, fever and inflammation [3]. Ketorolac tromethamine $\left(\mathrm{C}_{19} \mathrm{H}_{24} \mathrm{~N}_{2} \mathrm{O}_{6}\right)$ has a molecular weight $376.4 \mathrm{~g} / \mathrm{mol}$ and it was estimated by various analytical methods such as spectrophotometry [4-6], HPTLC [7,8], voltammetry [9], fluorophotometry [10], HPLC [11-13] and in biological fluids such as human plasma [14], human serum [15], human eye samples [16], serum and synovial fluids [17] and post mortem blood samples [18] in the literature. In the present study the authors have proposed five UV spectrophotometric methods for the determination of Ketorolac tromethamine in pharmaceutical dosage forms and the methods were validated as per ICH guidelines [19].

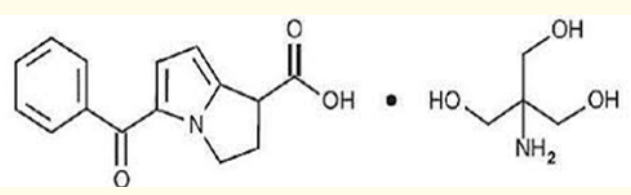

Figure 1: Chemical structure of ketorolac tromethamine.

\section{Materials and Methods}

Double beam spectrophotometer (SHIMADZU Model No. UV - 1800) with quartz cells was used for the present study. All the solutions were scanned at $200-400 \mathrm{~nm}$ range. Ketorolac tromethamine is available as tablets (Label claim: $10 \mathrm{mg}$ ) with brand name KETOROL-DT (Dr. Reddys), DENTAFORCE-DT (Mankind Pharma) and TORODENT-DT (Cipla Ltd). Ketorolac tromethamine was obtained as a gift sample from Cipla Ltd, India. Reagents such as phosphate buffer ( $\mathrm{pH}$ 5.0) and phosphate buffer ( $\mathrm{pH}$ 8.0), acetate buffer ( $\mathrm{pH} 4.7$ ), $0.1 \mathrm{~N} \mathrm{NaOH}$ and borate buffer ( $\mathrm{pH} 9.0$ ) and were prepared as per IP 2010.

\section{Procedure}

$25 \mathrm{mg}$ of Ketorolac tromethamine was accurately weighed and transferred in to a $25 \mathrm{ml}$ volumetric flask and dissolved in methanol $(1000 \mu \mathrm{g} / \mathrm{ml})$ and a series of dilutions were prepared with respective buffers as per the requirement. The reagents were prepared as given below.

\section{Preparation of phosphate buffer (pH 5.0)}

6.8 grams of potassium dihydrogen phosphate was dissolved in water and the $\mathrm{pH}$ was adjusted to 5.0 with $10 \mathrm{M}$ potassium hydroxide in a $1000 \mathrm{ml}$ volumetric flask.

\section{Preparation of phosphate buffer ( $\mathrm{pH} 8.0)$}

$50 \mathrm{ml}$ of $0.2 \mathrm{M}$ potassium dihydrogen phosphate was placed in a $200 \mathrm{ml}$ volumetric flask and $46.1 \mathrm{ml}$ of $0.2 \mathrm{M}$ sodium hydroxide was added and the volume was made up to $200 \mathrm{ml}$.

\section{Preparation of acetate buffer ( $\mathrm{pH} 4.7)$}

8.4 grams of sodium acetate and $3.35 \mathrm{ml}$ of acetic acid was dissolved in sufficient water to make $1000 \mathrm{ml}$ in a $1000 \mathrm{ml}$ volumetric flask.

\section{Preparation of $0.1 \mathrm{~N}$ sodium hydroxide}

4 grams of sodium hydroxide was dissolved in sufficient water and made up to $1000 \mathrm{ml}$ in $1000 \mathrm{ml}$ volumetric flask.

\section{Preparation of borate buffer (pH 9.0)}

6.20 grams of boric acid was dissolved in $500 \mathrm{ml}$ of water and the $\mathrm{pH}$ was adjusted with $1 \mathrm{M}$ sodium hydroxide (about $41.5 \mathrm{ml}$ ) 
and diluted with water to produce $1000 \mathrm{ml}$ in a $1000 \mathrm{ml}$ volumetric flask.

Method validation

Linearity

A series of Ketorolac tromethamine solutions 5 - $30 \mu \mathrm{g} / \mathrm{ml}$ were prepared using different buffer solutions - phosphate buffer $\mathrm{pH} 5$ (Method I), phosphate buffer pH 8 (Method II), acetate buffer $\mathrm{pH}$ 4.7 (Method III), $0.1 \mathrm{~N}$ sodium hydroxide (Method IV) and borate buffer pH 9 (Method V) and scanned against their reagent blank at range of $200-400 \mathrm{~nm}$. Ketorolac tromethamine has shown its $\lambda_{\max }$ at $323 \mathrm{~nm}$ in all methods. A calibration curve was drawn by taking the concentration on the $\mathrm{X}$-axis and their respective absorbance on the Y-axis for all the methods.

\section{Precision and accuracy}

Precision was studied by measuring the absorbance of 6 solutions of the same concentration $(n=6)$ and there by mean, standard deviation and relative standard deviation were calculated. Accuracy was studied by spiking the formulation solution of a fixed concentration with pure drug solution $(50 \%, 100 \%$ and $150 \%)$ by standard addition method and there by percentage recovery and relative standard deviation were calculated.

\section{Assay of ketorolac tromethamine tablets}

20 tablets of Ketorolac tromethamine of two different brands were procured from the local pharmacy store and extracted with methanol and further dilutions were made with respective buffers and assay was carried out for all the methods.

\section{Results and Discussion}

New spectrophotometric methods were developed for the determination of Ketorolac tromethamine in different reagents such as phosphate buffer (pH 5.0) (Method I), phosphate buffer (pH 8.0) (Method II), acetate buffer ( $\mathrm{pH} 4.7$ ) (Method III), NaOH (Method IV) and borate buffer ( $\mathrm{pH}$ 9.0) (Method V) respectively. The present methods were compared with the previously published spectrophotometric methods and summarized in table 1.

\begin{tabular}{|l|c|c|c|}
\hline \multicolumn{1}{|c|}{ Reagent } & $\begin{array}{c}\lambda_{\text {max }} \\
(\mathbf{n m})\end{array}$ & $\begin{array}{c}\text { Linearity } \\
(\boldsymbol{\mu g} / \mathbf{m L})\end{array}$ & Ref \\
\hline Distilled water & 322 & $2-14$ & 4 \\
\hline Ninhydrin & 570 & $50-250$ & 5 \\
\hline $\begin{array}{l}\text { 2,4-dinitrophenyl hydrazine } \\
\text { (Condensation reaction) } \\
\text { 7,7',8,8' Tetra cyano quinodi- } \\
\text { methane (Charge transfer } \\
\text { reaction) }\end{array}$ & 424 & $0.5-18.5$ & 6 \\
\hline $\begin{array}{l}\text { Phosphate buffer (pH 5.0) } \\
\text { Phosphate buffer (pH 8.0) }\end{array}$ & 323 & $2.0-50.0$ & \\
Acetate buffer (pH 4.7) & & $5-30$ & Present \\
0.1N NaOH & & & \\
Borate buffer (pH 9.0) & & & \\
\hline
\end{tabular}

The absorption spectrum of Ketorolac tromethamine has shown $\lambda_{\max }$ at $323 \mathrm{~nm}$ in all the reagents (Figure 2). Ketorolac tromethamine obeys Beer-Lambert's law over the concentration range 5 - $30 \mu \mathrm{g} / \mathrm{ml}$ in all the methods (Table 2). Calibration curves were drawn by taking the concentration on the x-axis and the corresponding absorbance on the y-axis. The linear regression equations are found to be $\mathrm{y}=0.0735 \mathrm{x}-0.0214$ (0.9978), $\mathrm{y}=0.067 \mathrm{x}$ 0.0023 (0.9983), $y=0.066 x+0.0158(0.9992), y=0.0733 x-0.0007$ (0.9994), $y=0.0764 x-0.0024(0.9966)$ in phosphate buffer $(\mathrm{pH}$ 5.0), phosphate buffer ( $\mathrm{pH} 8.0$ ), acetate buffer ( $\mathrm{pH} 4.7$ ), $0.1 \mathrm{~N} \mathrm{NaOH}$ and borate buffer ( $\mathrm{pH} 9.0$ ) respectively (Figure 3). The percentage RSD in precision and accuracy was found to be $<2$ in all the above methods indicating that the methods are accurate and precise. The Optical characteristics of Ketorolac tromethamine were shown in table 3. The percentage of purity (Assay) results of Ketorolac tromethamine in the marketed formulations were shown in table 4 and no interference of excipients was observed.

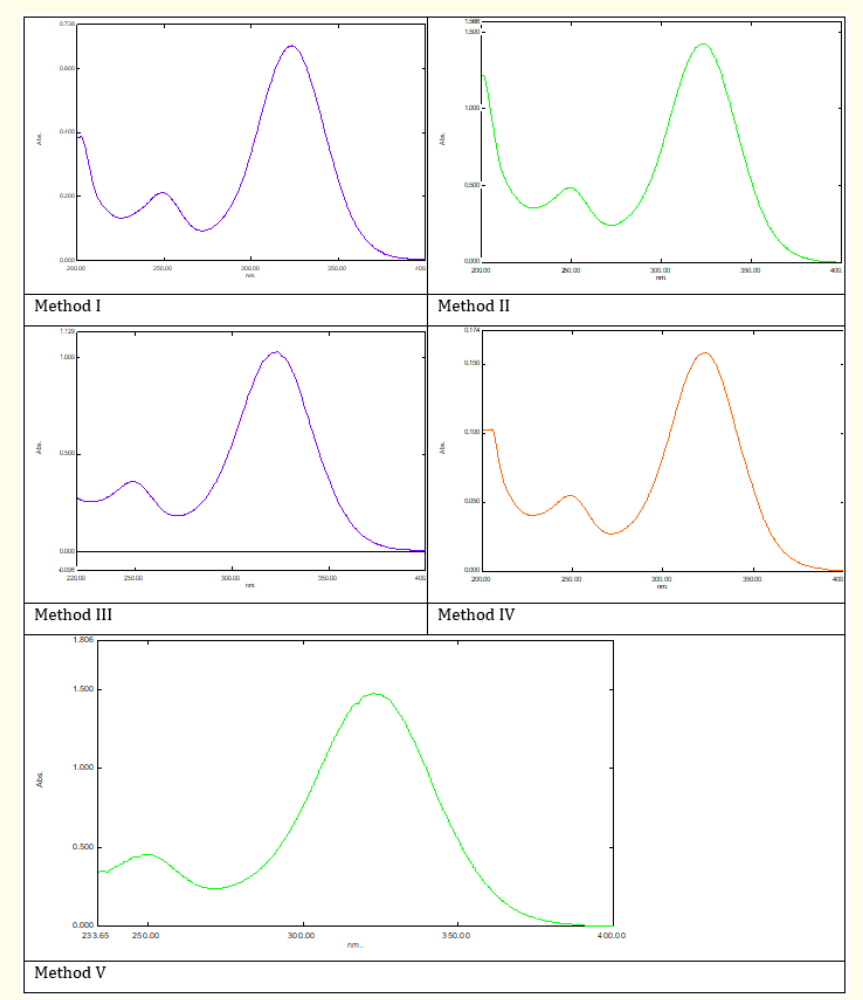

Figure 2: Absorption spectra of ketorolac $\mathrm{t}$ romethamine $(20 \mu \mathrm{g} / \mathrm{ml})$.

\begin{tabular}{|l|c|c|c|c|c|}
\hline \multirow{2}{*}{$\begin{array}{c}\text { Conc. } \\
(\boldsymbol{\mu g} / \mathbf{m l})\end{array}$} & \multicolumn{5}{|c|}{ Absorbance } \\
\cline { 2 - 6 } & Method I & $\begin{array}{c}\text { Method } \\
\text { II }\end{array}$ & $\begin{array}{c}\text { Method } \\
\text { III }\end{array}$ & $\begin{array}{c}\text { Method } \\
\text { IV }\end{array}$ & $\begin{array}{c}\text { Method } \\
\text { V }\end{array}$ \\
\hline 5 & 0.331 & 0.346 & 0.343 & 0.374 & 0.357 \\
\hline 10 & 0.671 & 0.717 & 0.677 & 0.741 & 0.745 \\
\hline 15 & 1.005 & 1.064 & 1.02 & 1.217 & 1.097 \\
\hline 20 & 1.352 & 1.429 & 1.374 & 1.501 & 1.482 \\
\hline 25 & 1.612 & 1.762 & 1.65 & 1.837 & 1.793 \\
\hline 30 & 2.044 & 2.246 & 1.976 & 2.338 & 2.218 \\
\hline
\end{tabular}

Table 2: Linearity of Ketorolac tromethamine.

Table 1: Review of spectrophotometric methods. 


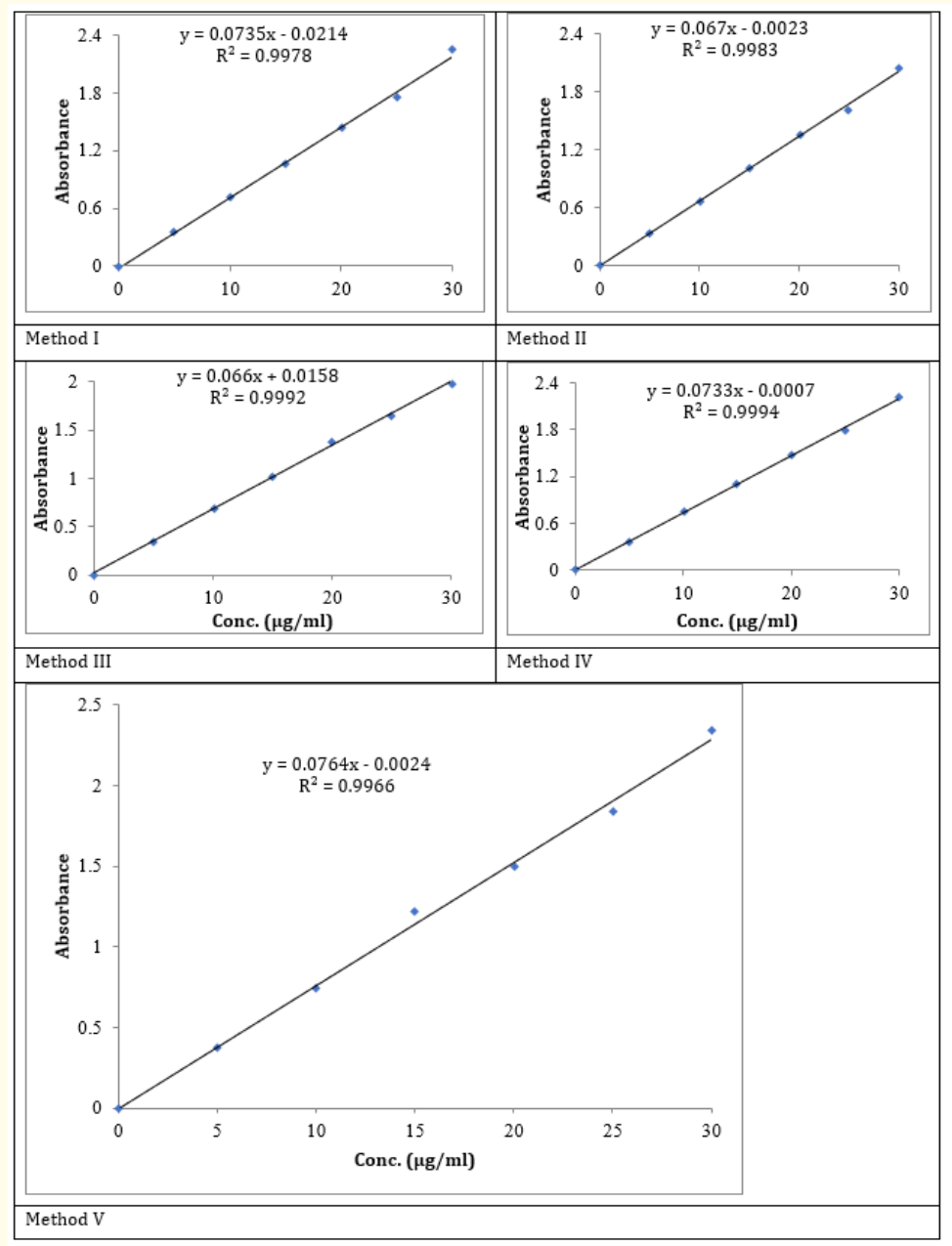

Figure 3: Calibration curves of ketorolac tromethamine.

\begin{tabular}{|c|c|c|c|c|c|c|}
\hline \multicolumn{2}{|c|}{ Parameters } & Method I & Method II & Method III & Method IV & Method V \\
\hline \multicolumn{2}{|c|}{ Linearity $(\mu \mathrm{g} / \mathrm{ml})$} & $5-30$ & $5-30$ & $5-30$ & $5-30$ & $5-30$ \\
\hline \multicolumn{2}{|l|}{$\lambda_{\max }(\mathrm{nm})$} & 323 & 323 & 323 & 323 & 323 \\
\hline \multicolumn{2}{|c|}{ Molar extinction coefficient (litre/ mole/ $\mathrm{cm}^{-1}$ ) } & $2.525 \times 10^{4}$ & $2.6987 \times 10^{4}$ & $2.5482 \times 10^{4}$ & $2.7891 \times 10^{4}$ & $2.8041 \times 10^{4}$ \\
\hline \multicolumn{2}{|c|}{ Sandell's sensitivity $\left(\mu \mathrm{g} / \mathrm{cm}^{2} / 0.001\right.$ absorbance unit) } & 0.01490 & 0.01394 & 0.01477 & 0.01349 & 0.01342 \\
\hline \multicolumn{2}{|l|}{ Slope } & 0.0735 & 0.067 & 0.066 & 0.0733 & 0.0764 \\
\hline \multicolumn{2}{|l|}{ Intercept } & -0.0214 & -0.0023 & 0.0158 & -0.0007 & -0.0024 \\
\hline \multicolumn{2}{|c|}{ Correlation coefficient } & 0.9978 & 0.9983 & 0.9992 & 0.9994 & 0.9966 \\
\hline \multirow{2}{*}{$\begin{array}{l}\text { Precision } \\
\text { (\%RSD) }\end{array}$} & Intraday & $0.81-1.02$ & $0.82-1.24$ & $0.77-0.91$ & $0.83-1.18$ & $0.87-1.24$ \\
\hline & Interday & $0.83-0.92$ & $0.78-1.21$ & $0.71-0.93$ & $0.88-1.13$ & $0.69-1.28$ \\
\hline \multicolumn{2}{|c|}{ Accuracy (\% RSD) } & $0.91-1.22$ & $0.87-1.18$ & $0.63-0.89$ & $0.58-0.99$ & $0.57-0.96$ \\
\hline
\end{tabular}

Table 3: Optical characteristics of Ketorolac tromethamine.

\begin{tabular}{|c|c|c|c|c|c|c|c|c|c|c|}
\hline \multirow{2}{*}{ Brand } & \multicolumn{2}{|c|}{ Method I } & \multicolumn{2}{c|}{ Method II } & \multicolumn{2}{c|}{ Method III } & \multicolumn{2}{c|}{ Method IV } & \multicolumn{2}{c|}{ Method V } \\
\cline { 2 - 10 } & $\begin{array}{c}\text { Observed } \\
\text { amount } \\
\text { (mg) }\end{array}$ & $\begin{array}{c}\text { \% } \\
\text { Recovery }\end{array}$ & $\begin{array}{c}\text { Observed } \\
\text { amount } \\
\text { (mg) }\end{array}$ & $\begin{array}{c}\text { \% } \\
\text { Recovery }\end{array}$ & $\begin{array}{c}\text { Observed } \\
\text { amount } \\
\text { (mg) }\end{array}$ & $\begin{array}{c}\text { \% } \\
\text { Recovery }\end{array}$ & $\begin{array}{c}\text { Observed } \\
\text { Amount (mg) }\end{array}$ & $\begin{array}{c}\text { \% } \\
\text { Recovery }\end{array}$ & $\begin{array}{c}\text { Observed } \\
\text { Amount } \\
\text { (mg) }\end{array}$ & $\begin{array}{c}\text { \% } \\
\text { Recovery }\end{array}$ \\
\hline I & 99.82 & 99.85 & 99.80 & 99.89 & 99.92 & 99.889 & 99.93 & 99.91 & 99.92 & 99.91 \\
\hline II & 99.86 & 99.83 & 99.85 & 99.85 & 99.91 & 99.91 & 99.90 & 99.788 & 99.84 & 99.94 \\
\hline
\end{tabular}

Table 4: Assay of ketorolac tromethamine (Label claim: $10 \mathrm{mg}$ ).

*Mean of three replicates. 


\section{Conclusion}

These five new spectrophotometric methods were validated and applied for the estimation of Ketorolac tromethamine in pharmaceutical formulations i.e. Tablets. The proposed methods are simple, precise, accurate, and economical. These methods can be successfully applied for the determination of Ketorolac tromethamine in pharmaceutical dosage forms and also for the kinetic studies of the biological samples.

\section{Acknowledgment}

The authors are grateful to M/s GITAM (Deemed to be University), Visakhapatnam for providing the research facilities and to Cipla Ltd for providing the gift samples of Ketorolac tromethamine.

\section{Bibliography}

1. Litvak KM and McEvoy GK. "Ketorolac, an injectable nonnarcotic analgesic". Clinical Pharmacology 9.12 (1990): 921-935.

2. Brown CR., et al. "Analgesic efficacy and safety of single-dose oral and intramuscular Ketorolac tromethamine for postoperative pain". Pharmacotherapy 10 (1990): 59S-70S.

3. Rooks WH., et al. "The analgesic and antiinflammatory profile of Ketorolac and its tromethamine salt". Drugs Under Experimental and Clinical Research 11.8 (1985): 479-492.

4. Rupinder Kaur P., et al. "Development and validation of UV Spectrophotometric method for the estimation of Ketorolac tromethamine in bulk drug". World Journal of Pharmacy and Pharmaceutical Sciences 5.4 (2016): 1792-1799.

5. Vandana PP., et al. "Validated spectrophotometric method for the estimation of Ketorolac tromethamine in bulk and tablets using ninhydrin: A modified approach". Asian Journal of Research Chemistry 7.1 (2014): 19-24.

6. Ismail NBS and Narayana B. "Spectrophotometric determination and spectroscopic studies on Schiff base and charge transfer complex of Ketorolac tromethamine". Journal of Analytical Science and Technology 6.32 (2015): 1-12.

7. Rao PLKM., et al. "Revalidation and analytical evaluation of Ketorolac tromethamine by HPTLC using reflectance scanning densitometry". International Journal of Chemical and Pharmaceutical Sciences 1.2 (2011): 129-134.

8. Devarajan PV., et al. "HPTLC determination of Ketorolac tromethamine". Journal of Pharmaceutical and Biomedical Analysis 22.4 (2000): 679-683

9. Squella JA., et al. "Voltammetric behavior of Ketorolac and its HPLC-EC determination in tablets". Analytical Letters 30.3 (1997): 553-564.

10. Prakash S and Meena S. "Fluoro photometric determination of Ketororlac tromethamine”. Indian Drugs 33 (1996): 149-151.

11. Sunil, G. et al., "Development and validation of Ketorolac tromethamine in eye drop formulation by RP-HPLC method". Arabian Journal of Chemistry 10.1 (2017): S928-S935.
12. Reddy P., et al. "Purity evaluation of ketorolac tromethamine by HPLC". Indian Drugs 30 (1993): 176-179.

13. Dubey SK., et al. "Rapid and sensitive reverse-phase high-performance liquid chromatography method for estimation of Ketorolac in pharmaceuticals using weighted regression". Indian Journal of Pharmaceutical Sciences 75.1 (2013): 89-93.

14. Wang Z., et al. "Determination of ketorolac in human plasma by reversed-phase high-performance liquid chromatography using solid-phase extraction and ultraviolet detection". Journal of Chromatography B: Biomedical Sciences and Applications 755.1-2 (2001): 383-386

15. Chaudhary RS., et al. "Reversed-phase high-performance liquid chromatography of Ketorolac and its application to bioequivalence studies in human serum". Journal of Chromatography 614.1 (1993): 180-184.

16. Demircan P., et al. "Determination of Ketorolac tromethamine in human eye samples by HPLC with photo diode-array detection". Chromatographia 66 (2007): s135-s139.

17. Franceschi L and Furlanut A. "Simple and sensitive HPLC method to monitor serum and synovial fluid concentrations of Ketorolac in reumathologic patients". Journal of Pharmaceutical and Biomedical Analysis 2.6 (2010): 121-124.

18. Logan BK., et al. "Analysis of Ketorolac in postmortem blood". Journal of Analytical Toxicology 19.2 (1995): 61-64.

19. ICH Q2 R1. validation of analytical procedures: Text and Methodology: November 2005.

\section{Assets from publication with us}

- Prompt Acknowledgement after receiving the article

- Thorough Double blinded peer review

- Rapid Publication

- Issue of Publication Certificate

- High visibility of your Published work

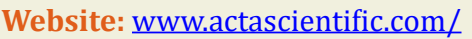

Submit Article: www.actascientific.com/submission.php Email us: editor@actascientific.com Contact us: +91 9182824667 